\title{
A genome scan for quantitative trait loci affecting cyanogenic potential of cassava root in an outbred population
}

\author{
Sukhuman Whankaew', Supannee Poopear', Supanath Kanjanawattanawong ${ }^{1}$, Sithichoke Tangphatsornruang ${ }^{2,3}$, \\ Opas Boonseng ${ }^{4}$, David A Lightfoot ${ }^{5}$ and Kanokporn Triwitayakorn ${ }^{1,3^{*}}$
}

\begin{abstract}
Background: Cassava (Manihot esculenta Crantz) can produce cyanide, a toxic compound, without self-injury. That ability was called the cyanogenic potential $(\mathrm{CN})$. This project aimed to identify quantitative trait loci (QTL) associated with the $\mathrm{CN}$ in an outbred population derived from 'Hanatee' $\times$ 'Huay Bong 60', two contrasting cultivars. CN was evaluated in 2008 and in 2009 at Rayong province, and in 2009 at Lop Buri province, Thailand. CN was measured using a picrate paper kit. QTL analysis affecting CN was performed with 303 SSR markers.

Results: The phenotypic values showed continuous variation with transgressive segregation events with more (115 ppm) and less CN (15 ppm) than either parent ('Hanatee' had 33 ppm and 'Huay Bong 60' had 95 ppm). The linkage map consisted of 303 SSR markers, on 27 linkage groups with a map that encompassed 1,328 cM. The average marker interval was 5.8 cM. Five QTL underlying CN were detected. CN08R1from 2008 at Rayong, CN09R1and CNO9R2 from 2009 at Rayong, and CNO9L1 and CNO9L2 from 2009 at Lop Buri were mapped on linkage group 2, 5, 10 and 11, respectively. Among all the identified QTL, CNO9R1 was the most significantly associated with the CN trait with LOD score 5.75 and explained the greatest percentage of phenotypic variation (\%Expl.) of 26\%.
\end{abstract}

Conclusions: Five new QTL affecting CN were successfully identified from 4 linkage groups. Discovery of these QTL can provide useful markers to assist in cassava breeding and studying genes affecting the trait.

\section{Background}

Throughout the world, cassava (Manihot esculenta Crantz) has been cultivated as an important food source and industrial feedstock since agriculture was developed. Accordingly, it ranked fourth among all crops in worldwide production. Thailand was the world's leading exporter [1]. As a cyanogenic crop, cassava has the ability to release hydrogen cyanide $(\mathrm{HCN})$ during cell damage $[2,3]$. Variation among cultivars in their cyanogenic potential $(\mathrm{CN})$, causes concerns about their possible health effects such as acute intoxication, manifested as vomiting, dizziness, etc. [4] and environmental toxicity [5]. Improved cassava cultivars with low $\mathrm{CN}$ and an improved understanding of genes affecting $\mathrm{CN}$ were of considerable interest.

\footnotetext{
* Correspondence: mbktw@mahidol.ac.th

'Institute of Molecular Biosciences, Mahidol University, Nakhon Pathom, Thailand

Full list of author information is available at the end of the article
}

$\mathrm{CN}$ was reported to be a quantitative trait [5]. Since conventional breeding was not effective or efficient with quantitative trait loci (QTL) of moderate to low heritability, molecular breeding was expected to be an efficient, reliable and cost effective breeding approach [6,7]. For molecular breeding, QTL analysis was often used to identify trait-linked markers in order to facilitate marker-assisted selection (MAS). QTL identification was not only used to assist breeding program, but also to gain understanding of the loci and underlying genes and their effects $[6,7]$.

In the present study, an $F_{1}$ outbred population was chosen for QTL analysis because that population structure required the least time to generate. The population provided the significant segregation of both genotype and phenotype as required for QTL discovery [8-10]. A large number of SSR markers for cassava have been developed [11-14]. These markers were used to construct a genetic
Ciomed Central

(c) 2011 Whankaew et al; licensee BioMed Central Ltd. This is an Open Access article distributed under the terms of the Creative Commons Attribution License (http://creativecommons.org/licenses/by/2.0), which permits unrestricted use, distribution, and reproduction in any medium, provided the original work is properly cited. 
linkage map in order to apply for identification of QTL underlying $\mathrm{CN}$ trait.

\section{Results and Discussion}

Phenotypic measurement

Variation in the $\mathrm{CN}$ in an outbred population derived from 'Hanatee' $\times$ 'Huay Bong 60' and its parents are shown in Table 1. In all evaluated years and locations, the $\mathrm{CN}$ of 'Hanatee' was approximately two folds lower than 'Huay Bong 60'.

The distribution of the $\mathrm{CN}$ in the population showed continuous variation, across a wide range (Table 1), typical of quantitative traits. That implied that $\mathrm{CN}$ would be underlain by polygenes. Transgressive variation was observed that may have resulted from cooperation or interaction among the loci and genes present in the two parental types. In addition, over-dominance and epitasis may also have contributed to the transgressive segregation [15]. The correlation coefficients ( $\mathrm{r}$ ) among years and locations ranked from 0.308 to 0.487 and showed significance at $P<0.01$ (Table 2). Therefore, the phenotypic data were appropriate for QTL analysis but mean data might be less informative than individual environments.

\section{Linkage map construction}

A total of 1,732 available SSRs consisting of 667 primer pairs provided from the International Center for Tropical Agriculture (CIAT) [16], 425 primer pairs from 640 primer pairs from Sraphet et al. (2011) [12] and Kunkeaw et al. (2011) [14] were tested for informative markers between the parental lines. Of these, 507 markers (28.9\%) were informative and successfully genotyped within the population. From genotypic data using 507 loci, the results showed that 151 markers $(\sim 30 \%)$ had distorted segregation ratios. Eleven markers $(\sim 2 \%)$ were $100 \%$ identical to other marker loci. Therefore, those 162 total DNA markers were excluded. The highly distorted segregation ratios found in this study were common among out-crossing species like cassava [17]

The linkage map (Figures 1, 2, 3, 4 and 5) consisted of 303 markers located on 27 linkage groups. The map
Table 2 The correlation coefficients

\begin{tabular}{lccc}
\hline & 2008, Rayong & 2009, Rayong & 2009, Lop Buri \\
\hline 2008, Rayong & 1 & & \\
2009, Rayong & $0.413\left(^{* *}\right)$ & 1 & \\
2009, Lop Buri & $0.308\left(^{* *}\right)$ & $0.487\left(^{* *}\right)$ & 1 \\
\hline
\end{tabular}

The correlation coefficients of cyanogenic potential among the lines of the population derived from 'Hanatee' $\times$ 'Huay Bong 60' in 2008 at Rayong, in 2009 at Rayong and in 2009 at Lop Buri.

** $=$ Significant at $P<0.01$.

covered 1,328 cM with average spacing between markers of $5.8 \mathrm{cM}$, smaller than the $10 \mathrm{cM}$ desirable for QTL detection by interval mapping (IM) [18-20]. Although the derived map had good potential to identify QTL, it was not yet a saturated map. More markers or inclusion of markers with distorted segregation ratios maybe required, to bring the number of linkage groups equal to the number of haploid genome $(\mathrm{n}=18)$.

The cassava genome database contained a draft sequence in late 2010 [21], in which there were 11,243 scaffolds spanning $416 \mathrm{Mb}$. The SSR loci used in the map were identified in the scaffolds. A total of 220 scaffolds were placed on the map. Of these, 50 scaffolds containing more than one marker locus from the same linkage group. However, 13 of 50 scaffolds were separated by markers from other scaffolds. For example, on the LG1, there were 44 loci which can be located on 31 scaffolds of the cassava genome sequences (Figures 1, 2, 3,4 and 5 ). Within the region between EME162 to CA226, scaffold11181 was separated by scaffold00476. The lack of correspondence of some marker orders in our genetic map with the physical order in the sequence of cassava may have resulted from inaccurate estimations of genetic distance based on recombination frequency. Errors might be found in both genetic maps and preliminary scaffold assemblies. Alternately, the difference in genetic background of the cassava used in the two studies may underlie the differences.

\section{QTL discovery}

Based on multiple-QTL models (MQM) analysis, only 5 QTL were detected across 4 linkage groups, 1-2 from

Table 1 Phenotypic values of outbred population and their parents

\begin{tabular}{|c|c|c|c|c|c|}
\hline & & \multicolumn{4}{|c|}{ Cyanogenic potential (ppm)* } \\
\hline & & 2008 at Rayong & 2009 at Rayong & 2009 at Lop Buri & Mean \\
\hline & Hanatee & $40.8 \pm 11.0$ & $22.8 \pm 11.0$ & $35.7 \pm 16.6$ & 33.3 \\
\hline \multirow[t]{2}{*}{ Mean } & Huay Bong 60 & $106.1 \pm 40.7$ & $57.9 \pm 32.9$ & $131.4 \pm 39.7$ & 95.0 \\
\hline & F1 progenies & $80.3 \pm 24.4$ & $35.0 \pm 15.5$ & $48.9 \pm 21.5$ & 55.2 \\
\hline \multicolumn{2}{|c|}{ Maximum } & 146.9 & 83.9 & 104.2 & 115 \\
\hline \multicolumn{2}{|c|}{ Minimum } & 38.4 & 10.8 & 14.3 & 25 \\
\hline
\end{tabular}

Mean values of cyanogenic potential plus or minius SEMs in the parents ('Hanatee' and 'Huay Bong 60') and their progenies from 2008 at Rayong, 2009 at Rayong and 2009 at Lop Buri, and maximum and minimum trait values of the progeny population

* mg HCN equivalents $\mathrm{kg}^{-1}$ fresh weight (ppm) 
1

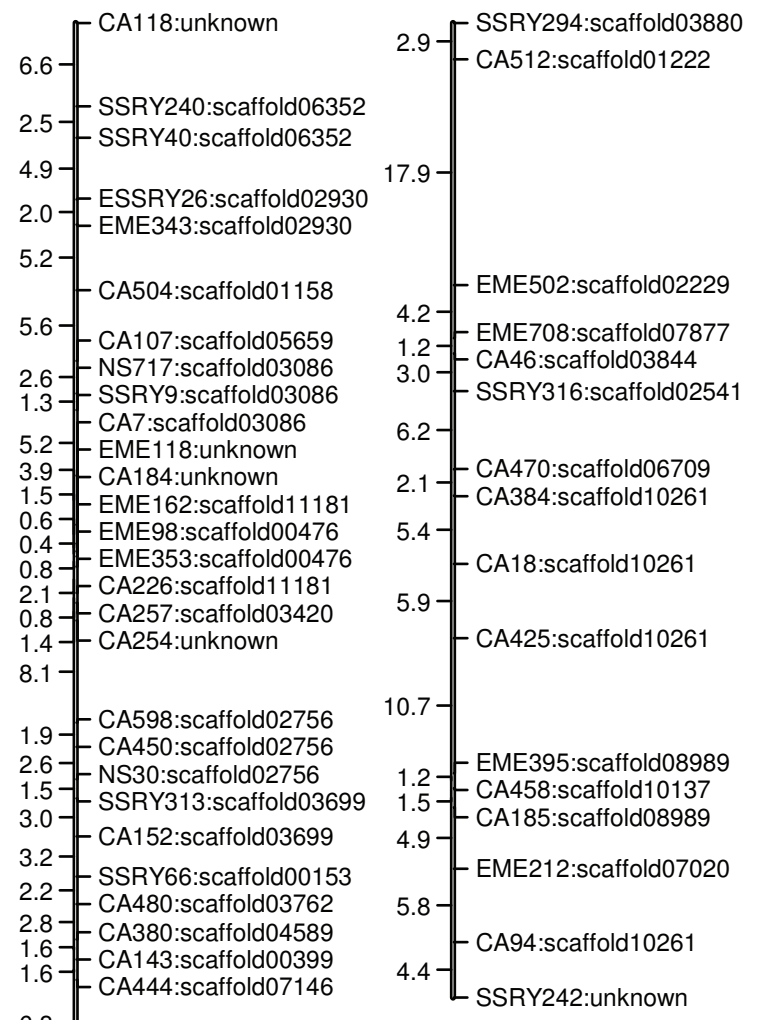

2
3

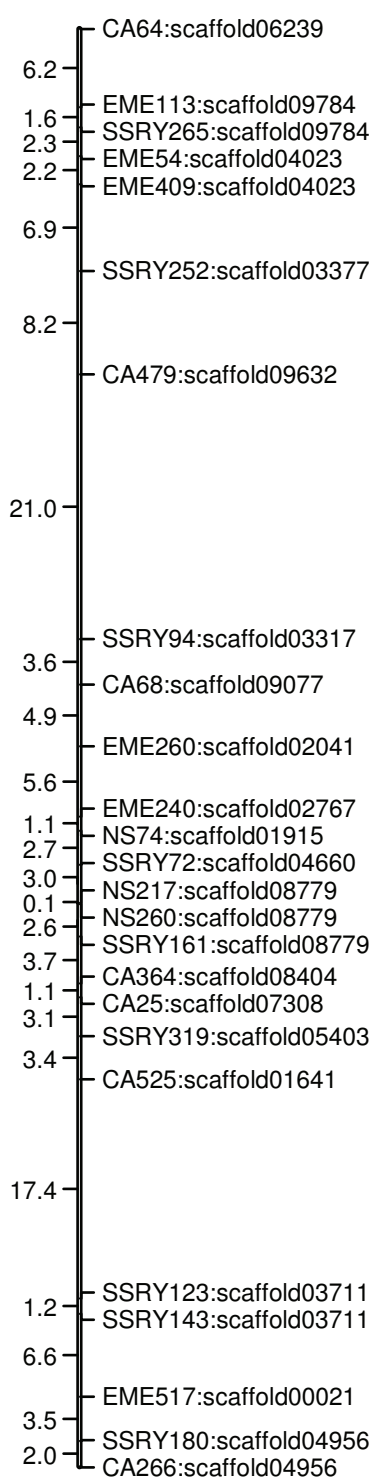

- CA146:scaffold01329

- SSRY192:scaffold03386

- CA368:scaffold05229

$10.1-$

2.0- SSRY92:scaffold00902

SSRY92:scaffold00902

$4.8-$ - EME272:scaffold07029

1.7 - SSRY269:scaffold03437

$0.5-1$ - CA343 scaffold 04817

1.9 - EME309:scaffold00672

3.8- CA74:scaffold03896

5.1

CA190:scaffold00485

- CA80:scaffold10639

$3.9-$ - CA104:scaffold10261

- SSRY268:scaffold00423

$0.9-$ - CA49:scaffold09007

10.1

L EME205:scaffold10165

Figure 1 Genetic linkage map of cassava based on SSR marker (LG1-3). The numbers above each bar indicated linkage group name. To the left hand side of each bar the number indicated interval distance in $\mathrm{CM}$. To the right hand side of each bar the number indicated locus name and scaffold of cassava genome that was anchored. 


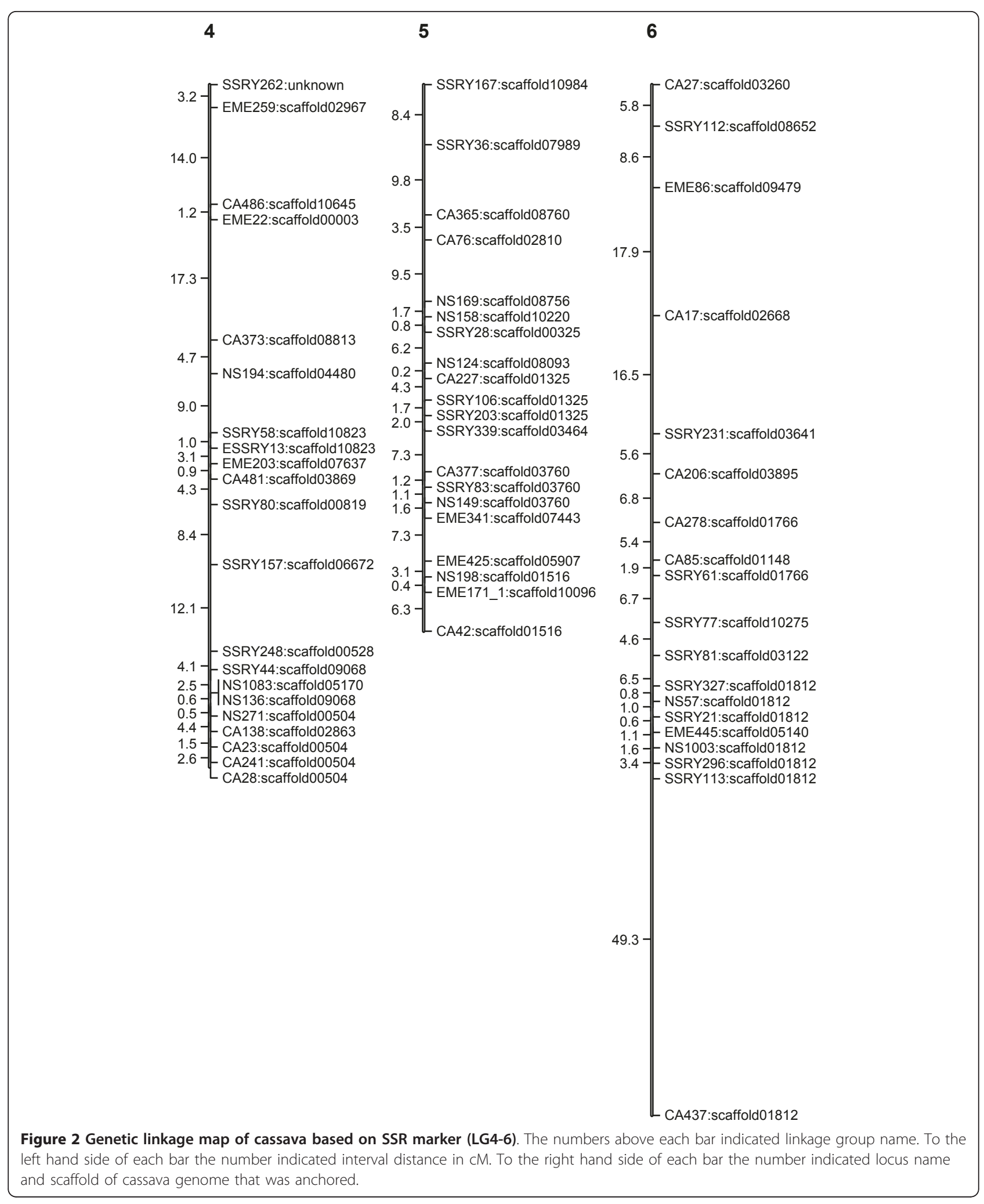




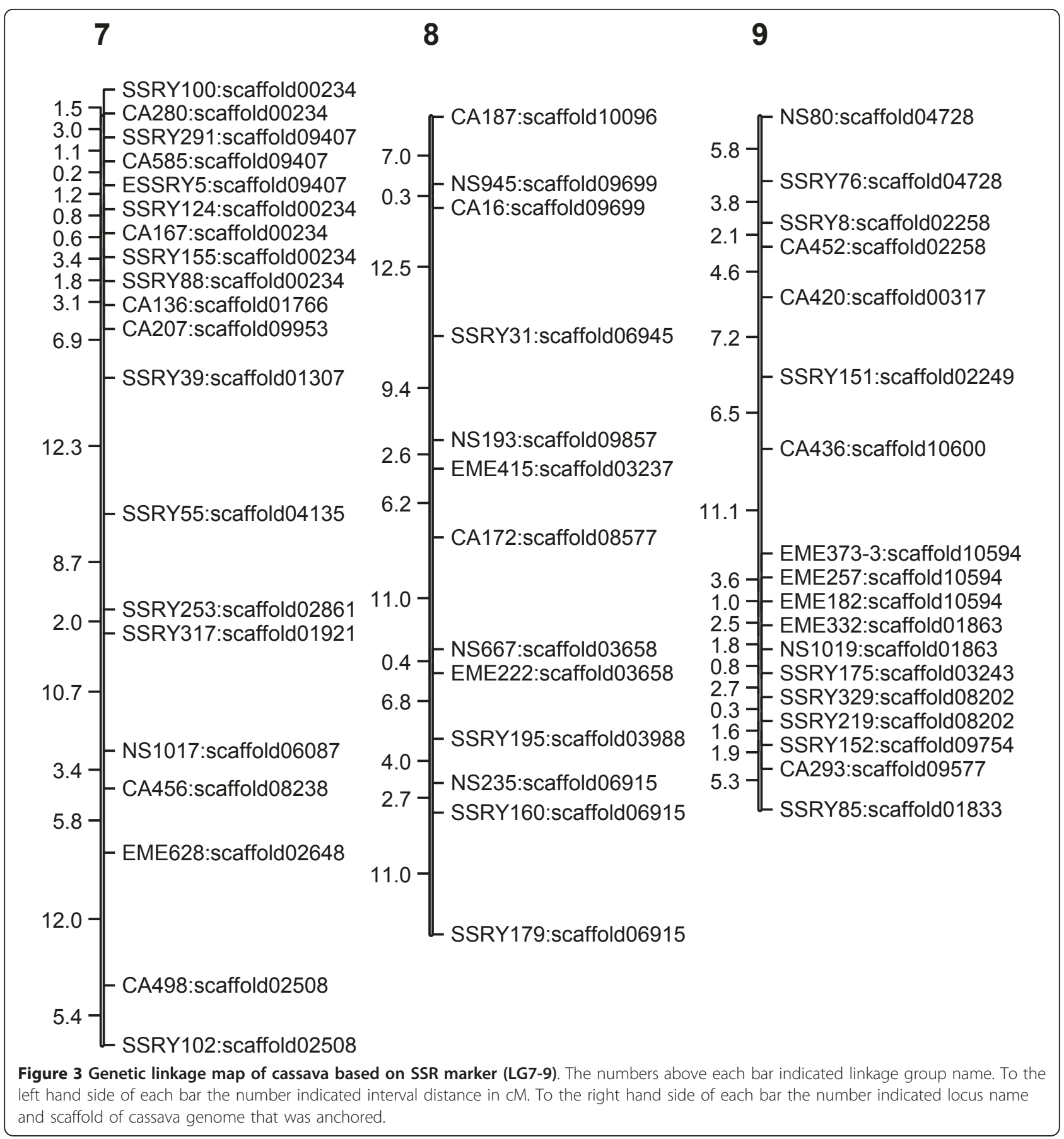

each environment (Table 3). Each QTL showed LOD scores that were higher than the chromosome wide significant threshold. The LOD scores of the QTL identified ranged from 3.77-5.75. The QTL with the largest effect had a LOD score higher than both chromosome and genome wide significant thresholds. CNO9R1 was located on linkage group 10 associated with marker locus CA141. In addition, CNO9R1 also explained the largest portion of variation at 26.
The LOD scores of some QTL were lower than genome wide significant threshold as expected for sparse maps (maps with marker density $>1 \mathrm{cM}$ ) [22,23]. However, for all QTL, the phenotype means indicated that one allele combination was markedly better at each location although the differences were not all significant. Therefore, many QTL were dependent on the environment. Equally, the large variation in $\mathrm{CN}$ found among environments showed a strong environmental effect 
10

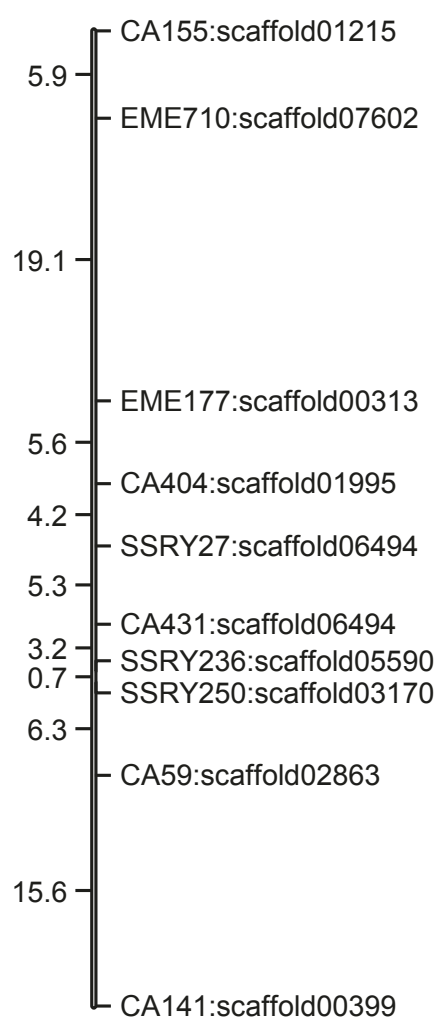

13

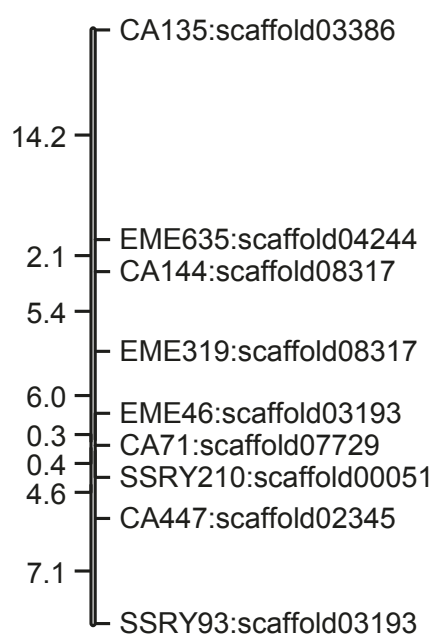

11

12

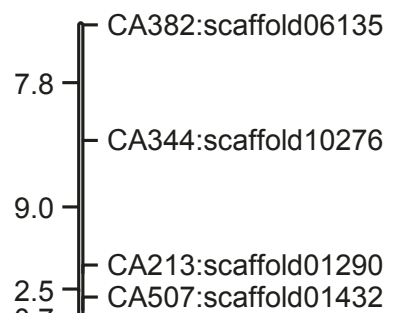

$0.7-[-$ SSRY145:scaffold01943

$5.0-$

- EME331:scaffold08309

$2.4-$ - CA482: scaffold06623

$0.7-$ - NS362:scaffold02968

$4.8-$

$1.4-$ NS847:scaffold08377

7.8

CA421:scaffold08377

$7.8-$

SSRY70:scaffold08377

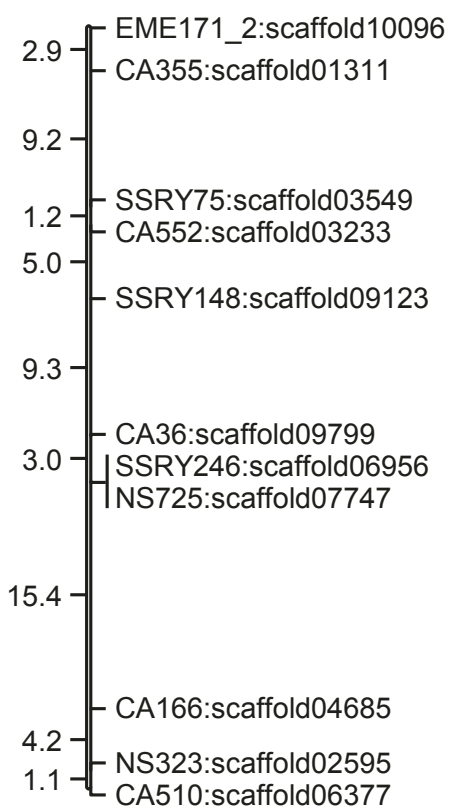

14

15

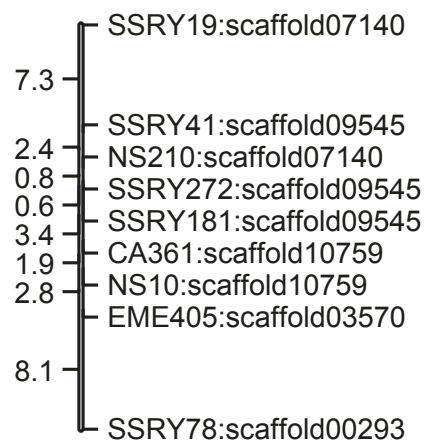

Figure 4 Genetic linkage map of cassava based on SSR marker (LG10-15). The numbers above each bar indicated linkage group name. To the left hand side of each bar the number indicated interval distance in cM. To the right hand side of each bar the number indicated locus name and scaffold of cassava genome that was anchored. 
16

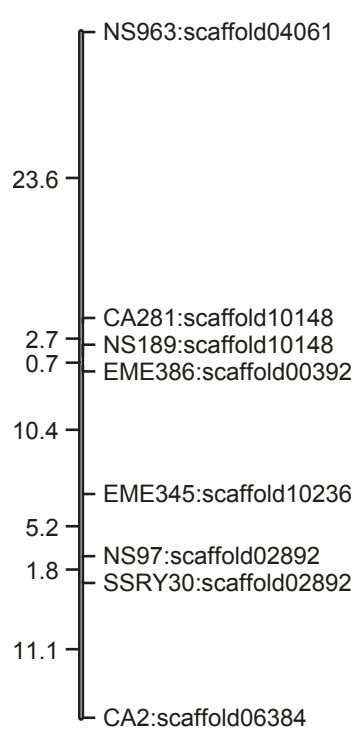

19
17

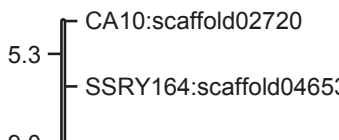

$7.3-$

$3.1-$ - SSRY63:scaffold 02720

$3.1-[$ CA387:scaffold00964
18

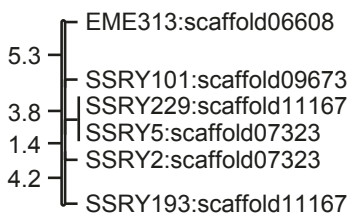

21

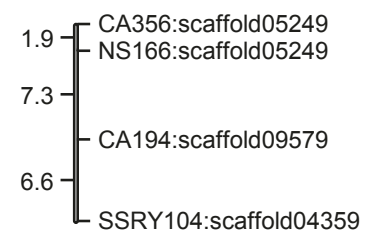

24
22

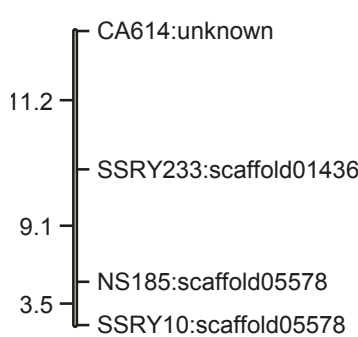

25
20

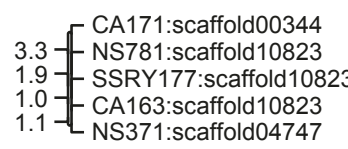

23 
Table 3 Description of five QTL for cyanogenic potential in cassava and their functional annotation

\begin{tabular}{|c|c|c|c|c|c|c|c|c|c|c|c|c|c|}
\hline \multirow[t]{2}{*}{ Environments } & \multirow[t]{2}{*}{ ag } & \multirow[t]{2}{*}{ QTLs } & \multirow[t]{2}{*}{ Loci } & \multirow[t]{2}{*}{ LG } & \multirow[t]{2}{*}{ ac } & \multirow[t]{2}{*}{ LOD } & \multirow[t]{2}{*}{$\begin{array}{c}\% \\
\text { expl }\end{array}$} & \multicolumn{4}{|c|}{$\begin{array}{l}\text { Phenotype mean } \\
(\mathrm{ppm})^{*}\end{array}$} & \multirow[t]{2}{*}{$\begin{array}{l}\text { Location on physical } \\
\text { map }\end{array}$} & \multirow[t]{2}{*}{ Functional annotation } \\
\hline & & & & & & & & $\mathrm{ac}$ & $\mathrm{ad}$ & $\mathrm{bc}$ & $\mathrm{bd}$ & & \\
\hline Rayong, 2008 & 4.4 & CN08R1 & CA227 & 5 & 3.0 & 3.77 & 16.1 & 92.0 & 72.2 & 70.4 & 88.3 & Scaffold08093 at $10.8 \mathrm{kbp}$ & Unknown \\
\hline \multirow[t]{2}{*}{ Rayong, 2009} & 4.5 & CN09R1 & CA141 & 10 & 2.8 & 5.75 & 26.0 & 23.4 & 29.6 & 26.5 & 45.6 & $\begin{array}{l}\text { Scaffold00399 at } 564.7 \\
\text { kbp }\end{array}$ & Unknown \\
\hline & & CN09R2 & CA344 & 11 & 2.4 & 4.05 & 15.9 & 23.4 & 31.2 & 20.1 & 36.5 & Scaffold 10276 at $15 \mathrm{kbp}$ & $\begin{array}{l}\text { Nucleotide-binding protein of } 35 \\
\text { kDa }\end{array}$ \\
\hline \multirow[t]{2}{*}{ Lop Buri, 2009} & 4.4 & CNOSLI & CA18 & 2 & 3.0 & 4.58 & 23.0 & 62.3 & 50.4 & 80.3 & 61.9 & Scaffold10261 at $564 \mathrm{kbp}$ & $\begin{array}{c}\beta-1,3-N-\text { Acetylglucosaminyl } \\
\text { transferase }\end{array}$ \\
\hline & & CNO9L2 & CA76 & 5 & 3.2 & 4.22 & 18.5 & 62.3 & 38.2 & 41.6 & 51.9 & $\begin{array}{l}\text { Scaffold02810 at } 207.3 \\
\text { kbp }\end{array}$ & $\begin{array}{l}\text { Adenosine/Guanosine } \\
\text { diphosphatase }\end{array}$ \\
\hline
\end{tabular}

Genetic metrics for each QTL: Detail of each QTL affecting cyanogenic potential from evaluating in 2008 at Rayong (RY08), 2009 at Rayong (RY09) and 2009 at Lop Buri (LB09).

ac Chromosome wide significance threshold.

$\alpha$ Genome wide significance threshold.

\%expl Percentage of phenotypic variation explain.

* $\mathrm{mg} \mathrm{HCN}$ equivalents $\mathrm{kg}^{-1}$ fresh weight (ppm).

(Table 2). The percentage of phenotypic variation explained (\%Expl.) from all detected QTL ranged from $15.9-26.0 \%$ (Table 3).

Although MQM showed the highest precision to identify and map QTL, Kruskal-Willis (KW) analysis was used for single marker analysis to avoid type 2 errors. Except for CN08R1, all identified QTL showed significance by KW analyses (Figure 6). Even though CNO8R1 did not show significance by KW analysis, loci flanking this QTL showed strong significance. That suggested that all loci detected were the real QTL not type 1 errors $[6,24]$. No common QTL was found across all environments (Table 3), which may be because the $\mathrm{CN}$ was highly sensitive to environment [4]. However, KW analysis of CNO9R2 showed significant association with $\mathrm{CN}$ across all environments.

In a previous study by Kizito et al. (2007) [25] two QTL for CN were found linked to loci SSRY105 and SSRY242. The locus SSRY105 was not polymorphic in the current map, but SSRY242 was found on linkage group 2 as was CNO9L1. However, SSRY242 was 34.4 $\mathrm{cM}$ far from the position of CNO9L1. It should be kept in mind that QTL analysis is based on statistical analysis and there is a strong environmental effect on $\mathrm{CN}$ [4]. Therefore, individual QTL may not be found only in specific populations or environments. However, this study helped develop markers to assist in cassava improvement, and for the study of genes affecting to $\mathrm{CN}$ and for comparative mapping in other related species.

In addition, functional gene annotation of the regions within 2-LOD support of each QTL was performed. A total of 159 annotated genes, consisting of 4, 18, 19, 106 and 12 predicted genes underlying the regions of CNO8R1, CNO9R1, CNO9R2, CNO9L1 and CNO9L2, respectively were identified (Additional file 1). Interestingly, three annotated genes at the QTL peaks have been predicted including; a nucleotide-binding protein of $35 \mathrm{kDa}$ (Nbp35; EC 3.6.1.15), $\beta-1,3-\mathrm{N}$-acetylglucosaminyl transferase (EC 2.4.1.149) and an adenosine/guanosine diphosphatase (EC 3.6.1.6) within intervals that contained QTL CNO9R2, CN09L1 and CNO9L2, respectively (Table 3). Nbp35 belongs to subgroup of the P loop NTPases which perform a wide variety of cellular functions such as signal transduction, signal-sequence recognition, protein transport and localization, chromosome partitioning, etc. [26]. Nbp35 was an iron-sulfur protein with a dual localization in the cytosol and nucleus. It played a direct role in biogenesis and was essential for eukaryotic metal ion insertion in proteins and membrane transport [27].

Adenosine/guanosine diphosphatases were nucleoside diphosphatase acting on hydrolysis of phosphoric ester. One of the substrates for this enzyme was nucleoside diphosphate which is generated by glycosyltransferase in the fungal, plant, and mammalian cell secretory pathways [28]. The conversion of nucleoside diphosphate by nucleoside diphosphatase yields monophosphates which relieve inhibition of the transfer enzymes and provide substrates for antiport transport systems by which the entrance of nucleotide sugars from the cytosol into the secretory pathway lumen was mediated. However, the absence of diphosphatase activity does not end glycosylation or the entrance of nucleotide sugars into lumen [29].

$\beta-1,3-\mathrm{N}$-Acetylglucosaminyl transferase belongs to the glycosyltransferase family of enzymes. They act to catalyze the transfer of a sugar (monosaccharide) unit from a sugar nucleotide derivative to a sugar or amino acid acceptor (EC2.4.-) [30]. Cyanogenic glycosides are 


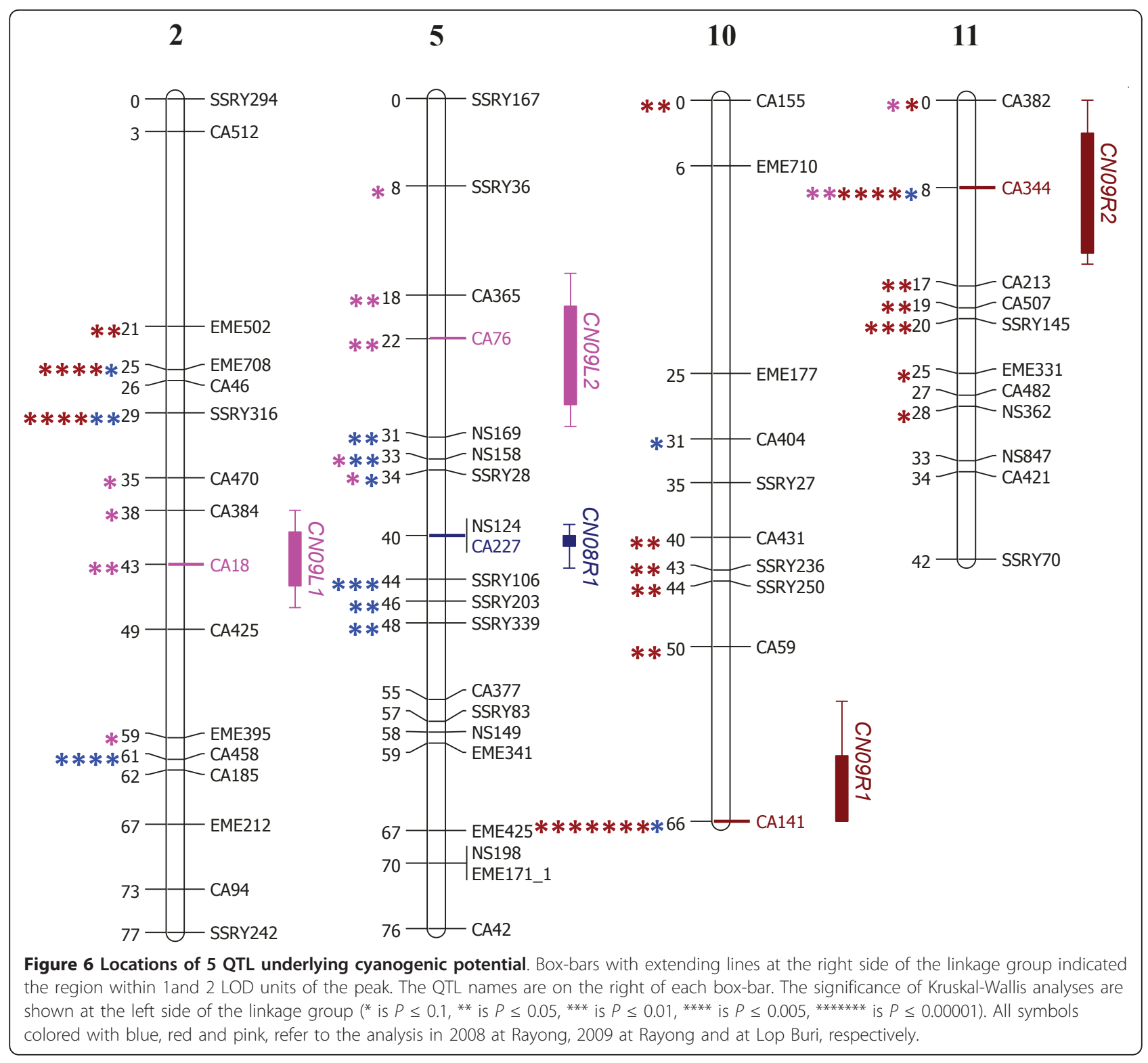

precursors of $\mathrm{HCN}$ in cyanogenesis pathway [31]. To produce linamarin and lotaustralin, which are cyanogenic glycosides in cassava, the glcosyltransferase must catalyze L-valine and L-isoleucine [32], and thus the gene encoding this $\beta-1,3-\mathrm{N}$-acetylglucosaminyl transferase might be involved in this process.

There is no report to link Nbp35 and Adenosine/Guanosine diphosphatase directly to the cyanogenesis pathway, however these two enzymes were involved in common biogenesis. In addition, sequences of linamarase (EC 3.2.1.21) and hydroxynitrile lyase (4.1.2.11) which are key enzymes involved in the cyanogenesis pathway were found on scaffold09743 and scaffold01206, respectively. However, these scaffolds were not anchored by any of the markers in this study linkage map. Thus, it would be useful to identify additional markers to link these enzymes to the map.

\section{Conclusions}

In this study, an SSR based genetic linkage map of cassava was constructed using an $F_{1}$ population of a cross between 'Hanatee' and 'Huay Bong 60'. The map was used for analysis of QTL underlying $\mathrm{CN}$, and five potential QTL were detected. Among all the QTL, CN09R1, which was located on linkage group 10 was the strongest with the LOD value of 5.75 and it explained $26.0 \%$ of the variation in $\mathrm{CN}$. In addition, all loci on the genetic map were compared with the data from cassava genome sequence. The anchor markers common to both could help the organizing and completion of 
chromosome sized scaffolds. The loci found in this study will be useful for identification of genes controlling the traits as well as establishing MAS of cassava in the future.

\section{Methods}

\section{Plant materials and field experiment}

Cassava variety 'Hanatee' (Thai local variety), exhibited low CN and 'Huay Bong 60' (commercial variety) [33], displayed high $\mathrm{CN}$. They were used as female and male parent, respectively. A hundred of their progeny were used for the mapping population.

All samples were planted in May during years 2007 2008. In 2007, the population and its parents were separately cultivated at Rayong province, Thailand. Ten cutting stems per genotype were planted with ten rows at a space of $1 \times 1.5 \mathrm{~m}$. In 2008 , they were cultivated at Rayong and Lop Buri provinces, Thailand. Each genotype was replicated two times in $10 \times 10$ simple lattice designs at a space of $0.8 \times 1 \mathrm{~m}$. Fertilizer $(\mathrm{N}: \mathrm{P}: \mathrm{K}$; $15: 15: 15), 312.5 \mathrm{~kg} /$ Hectare and chicken manure, 3,100 $\mathrm{kg} /$ Hectare were applied at one month after planting. Pest management was applied as necessary. Roots were harvested for $\mathrm{CN}$ evaluation at one year after planting. The climate at both locations was warm and humid all year round with an average temperature of $28^{\circ} \mathrm{C}$. The average rainfall at Rayong and Lop Buri was 1,339.4 and $1,211.9 \mathrm{~mm}$ per year [34], respectively. There were different soil types at Rayong (clayey loam soil) and Lop Buri (clay soil) [35]. There was no evidence of pests and diseases that occurred in the planted areas.

\section{Monitoring the $\mathrm{CN}$}

The $\mathrm{CN}$ was evaluated in roots as $\mathrm{mg} \mathrm{HCN}$ equivalents $\mathrm{kg}^{-1}$ fresh weight (ppm) using picrate paper kit as described by Bradbury et al. (1999) [36]. The roots of the population and its parents were harvested in 2008 at Rayong, and in 2009 at Rayong and at Lop Buri. In 2008 at Rayong, three plants of each genotype were selected, and three roots of each plant were collected. In 2009 at Rayong and Lop Buri, two plants of each genotype of each replication were used.

\section{SSR analysis}

Genomic DNA of the population and its parents was extracted from young leaves based on $\mathrm{CTAB}$ selective precipitation of DNA, modified according to Fulton et al. (1995) [37]. A total of 1,732 SSRs were used consisting of 667 SSRs provided by CIAT, 640 SSRs from Sraphet et al. (2011) [12] and 425 SSRs from Kunkeaw et al. (2011) [14]. They were screened against the parents to find informative markers used to genotyped the $F_{1}$ population. The PCR reactions were carried out in $20 \mu \mathrm{l}$ final volume containing $50 \mathrm{ng}$ of genomic DNA, $1 \times$
PCR buffer (Promega, Madison WI, USA) with $1.5 \mathrm{mM}$ $\mathrm{MgCl}_{2}, 0.2 \mu \mathrm{M}$ of each PCR primer, $200 \mathrm{mM}$ of each $\mathrm{dNTP}$ and one unit of DNA-polymerase (Promega). The PCR program for SSR amplification consisted of the following steps: $94^{\circ} \mathrm{C}$ for 2 min followed by 35 cycles of $94^{\circ} \mathrm{C}$ for $30 \mathrm{~s}, 55^{\circ} \mathrm{C}$ for $45 \mathrm{~s}$ and $72^{\circ} \mathrm{C}$ for $1 \mathrm{~min}$, then a final step of $72^{\circ} \mathrm{C}$ for 5 min (modified from Tangphatsornruang et al. (2008) [13]). Products were analyzed using $5 \%$ denaturing polyacrylamide gel electrophoresis and were visualized by silver staining according to Benbouza et al. (2006) [38]. The amplicon band patterns were scored according CP codes (eg. <abxcd $>$, <efxeg>, $<$ lmxll $>$, <nnxnp $>$ and $<$ hkxhk $>$ ) and missing data was replaced by "-" as described by Ooijen and Voorrips (2001) [39].

\section{Linkage map construction}

For linkage map construction, all genotypic data were loaded into JoinMap ${ }^{\circledR} 3.0$ program software [39]. The program first tested the segregation ratio of each marker using chi-square $\left(\chi^{2}\right)$ test. Statistically, significant markers at $P<0.05$ were excluded from further analysis. The similarity of loci was then tested and markers showing $100 \%$ similarity were also excluded. The remaining markers were mapped into linkage groups based on the LOD threshold of 6.0 and maximum recombination threshold of 0.4 . The genetic distance in a unit of recombinant frequency or centimorgan (cM) was calculated using Kosambi mapping function.

\section{QTL analysis}

As a first step, the data file containing the marker observations, the mean trait values and the genetic linkage map (output from JoinMap ${ }^{\circledR}$ 3.0) were loaded into MapQTL ${ }^{\circledR} 4.0$ program [9]. IM analysis was performed followed by permutation tests in order to determine the significance threshold of LOD score. The markers that showed LOD scores from IM higher than the chromosome wide threshold with $P<0.05$ from the 1,000 permutations were selected as the cofactor. The automatic cofactor selection tool was used for selection of cofactors. They were selected by user before performed MQM mapping analysis. The markers that showed LOD score higher than the chromosome wide threshold with $P<0.05$ from the 1,000 permutations were identified as QTL. KW analysis, a single marker analysis, was also analyzed based on one way ANOVA.

\section{Blast analysis and functional annotation}

On-line BLAST against the cassava genome with primer sequences located on linkage map was performed on Phytozome [21]. Functional annotation of each QTL was identified based on the Panther classification system [30]. 


\section{Additional material}

\section{Additional file 1: List of annotated genes within 2-LOD support} regions of the $\mathrm{QTL}$

\section{Acknowledgements}

This research was supported by National Center for Genetic Engineering and Biotechnology, Thailand, the Commission on Higher Education, Ministry of Education, Thailand, the Thailand Research Fund and Mahidol University. Financial support from the Thailand Research Fund through the Royal Golden Jubilee Ph.D. program (Grant No. PHD 4LMU/51/W1) to SW and KT is acknowledged.

\section{Author details}

${ }^{1}$ Institute of Molecular Biosciences, Mahidol University, Nakhon Pathom, Thailand. ${ }^{2}$ National Center for Genetic Engineering and Biotechnology, Bangkok, Thailand. ${ }^{3}$ Center for Cassava Molecular Biotechnology, Faculty of Science, Mahidol University, Bangkok, Thailand. ${ }^{4}$ Rayong Filed Crops Research Center, Ministry of Agriculture and Cooperatives, Rayong, Thailand. ${ }^{5}$ Plant Biotechnology and Genomics Core-Facility, Department of Plant, Soil, and Agricultural Systems, Southern Illinois University, Carbondale, IL 62901, USA.

\section{Authors' contributions}

SW and KT conceived of the study together with the other authors, carried out the major part of the experiments, analyzed the results and prepared the manuscript. SP and SK participated in the genotypic analysis. ST involved in the data analysis. OB prepared plant materials. DAL was involved in drafting the manuscript and revising it critically. All authors read and approved the final manuscript.

Received: 10 June 2010 Accepted: 25 May 2011 Published: 25 May 2011

\section{References}

1. FAO: Food Outlook - June 2007. In Food Outlook. Volume 1. Economic and Social Development Department; 2007.

2. White WLB, Arias-Garzon DI, McMahon JM, Sayre RT: Cyanogenesis in Cassava. The Role of Hydroxynitrile Lyase in Root Cyanide Production. Plant Physiol 1998, 116:1219-1225.

3. Iglesias CA, Sanchez T, Yeoh H-H: Cyanogens and linamarase activities in storage roots of cassava plants from breeding program. J Food Compos Anal 2002, 15:379-387.

4. Bokanga M, Ekanayake IJ, Dixon AGO, Porto MCM: Genotype-environment interactions for cyanogenic potential in cassava. Acta Hort 1994, 375:131-140

5. Dixon AGO, Asiedu R, Bokanga M: Breeding of cassava for low cyanogenic potential: problems, progress and perspectives. Acta Hort 1994, 375:153-161.

6. Collard BCY, Jahufer MZZ, Brouwer JB, Pang ECK: An introduction to markers, quantitative trait loci (QTL) mapping and marker-assisted selection for crop improvement: The basic concepts. Euphytica 2005, 142:169-196.

7. Xinyou Y, Stam P, Kropff JM, Schapendonk HCM: Crop modeling, QTL mapping, and their complementary role in plant breeding. Agron J 2003, 95:90-98.

8. Schneider K: Mapping populations and principles of genetic mapping. In The handbook of plant genome mapping. Edited by: Meksem K, Kahl G. Weinheim: WILEY-VCH Verlag GmbH 2005:3-19.

9. Van Ooijen JW, Boer MP, Jansen RC, Maliepaard C: MapQTL 4.0, Software for the calculation of QTL positions on genetic maps Plant Research International, Wageningen, The Netherlands; 2002.

10. Chenoweth SF, Visscher PM: Association mapping in outbred populations: Power and efficiency when genotyping parents and phenotyping progeny. Genetics 2009, 181:755-765.

11. Anderson JV, Delseny M, Fregene MA, Jorge V, Mba C, Lopez C, Restrepo S, Soto $M$, Piegu B, Verdier $V$, et al: An EST resource for cassava and other species of Euphorbiaceae. Plant Mol Biol 2004, 56:527-539.

12. Sraphet S, Boonchanawiwat A, Tangphatsornroung S, Boonseng O, Tabata S, Lightfoot DA, Triwitayakorn K: Development of simple sequence repeat markers and construction of genetic linkage map of cassava (Manihot esculenta Crantz). Theor Appl Genet 2011, 122:1161-1170.

13. Tangphatsornruang S, Sraphet S, Singh R, Okogbenin E, Fregene M, Triwitayakorn K: Development of polymorphic markers from expressed sequence tags of Manihot esculenta Crantz. Mol Ecol Res 2008, 8:682-685

14. Kunkeaw S, Yoocha $T$, Sraphet $S$, Boonchanawiwat $A$, Boonseng $O$ Lightfoot D, Triwitayakorn K, Tangphatsornruang S: Construction of a genetic linkage map using simple sequence repeat markers from expressed sequence tags for cassava (Manihot esculenta Crantz). Mol Breed 2011, 27:67-75.

15. Rieseberg LH, Archer MA, Wayne RK: Transgressive segregation, adaptation and speciation. Heredity 1999, 83:363-372.

16. International Center for Tropical Agriculture:[http://www.ciat.cgiar.org]

17. Okogbenin E, Marin J, Fregene M: An SSR-based molecular genetic map of cassava. Euphytica 2006, 147:433-440.

18. Beckmann JS, Soller M: Detection of linkage between marker loci and loci affecting quantitative traits in crosses between segregating populations. Theor Appl Genet 1988, 76:228-236.

19. Darvasi A, Weinreb A, Minke V, Weller Jl, Soller M: Detecting marker-QTL linkage and estimating QTL gene effect and map location using a saturated genetic map. Genetics 1993, 134:943-951.

20. Nadeau JH, Frankel WN: The roads from phenotypic variation to gene discovery: mutagenesis versus QTLs. Nat Genet 2000, 25:381-384.

21. Cassava Genome Project: 2009 [http://www.phytozome.net/cassava]

22. Van Ooijen JW: LOD significance thresholds for QTL analysis in experimental populations of diploid species. Heredity 1999, 83:613-624.

23. Atienza SG, Satovic Z, Petersen KK, Dolstra O, Martín A: Identification of QTLs influencing agronomic traits in Miscanthus sinensis Anderss. I. Total height, flag-leaf height and stem diameter. Theor App/ Genet 2003, 107:123-129.

24. Vinne D, Causse M: Mapping and characterising quantitative trait loci. In Molecular markers in plant genetics and biotechnology. Edited by: Vienne D. New Hampshire, USA: Science Publishers, Inc.; 2003:89-124.

25. Kizito EB, Ann-Christin R-W, Thomas E, Urban G, Martin F, Anna W: Quantitative trait loci controlling cyanogenic glucoside and dry matter content in cassava (Manihot esculenta Crantz) roots. Hereditas 2007, 144:129-136.

26. Leipe DD, Wolf $\mathrm{YI}$, Koonin EV, Aravind L: Classification and evolution of Ploop GTPases and related ATPases. J Mol Biol 2002, 317:41-72.

27. Hausmann A, Aguilar Netz DJ, Balk J, Pierik AJ, Muhlenhoff U, Lill R: The eukaryotic P loop NTPase Nbp35: an essential component of the cytosolic and nuclear iron-sulfur protein assembly machinery. Proc Nat/ Acad Sci 2005, 102:3266-3271

28. D'Alessio C, Trombetta ES, Parodi AJ: Nucleoside diphosphatase and glycosyltransferase activities can localize to different subcellular compartments in schizosaccharomyces pombe. J Biol Chem 2003, 278:22379-22387.

29. D'Alessio C, Caramelo JJ, Parodi AJ: Absence of nucleoside diphosphatase activities in the yeast secretory pathway does not abolish nucleotide sugar-dependent protein glycosylation. J Biol Chem 2005, 280:40417-40427.

30. Panther Database:[http://www.pantherdb.org].

31. McMahon JM, White WLB, Sayre RT: Cyanogenesis in cassava (Manihot esculenta (rantz). J Exp Bot 1995, 46:731-741.

32. Conn EE: Cyanogenesis: A personal perspective. Acta Hort 1994, 375:31-44

33. Vichukit V, Poolsaguan P, Rojanaridpiched C, Sarobol E, Jiamjumnanja J, Kittipadakul P, Changlek P, Taweechai N, Sriroth K, Piyachomkwan K: New cassava variety "MKUC 34-114-206". 41st Kasetsart University Annual Conference; Kasetsart University, Bangkok, Thailand Kasetsart University; 2003.

34. Thai meteorological department:[http://www.tmd.go.th/en].

35. Thai Tapioca Starch Association:[http://www.thaitapiocastarch.org/ article14_th.asp].

36. Bradbury MG, Egan SV, Bradbury JH: Picrate paper kits for determination of total cyanogens in cassava roots and all forms of cyanogens in cassava products. J Sci Food Agri 1999, 79:593-601.

37. Fulton T, Chunwongse J, Tanksley S: Microprep protocol for extraction of DNA from tomato and other herbaceous plants. Plant Mol Biol Rep 1995 13:207-209. 
38. Benbouza $\mathrm{H}$, Jacquemin J-M, Baudoin J-P, Mergeai G: Optimization of a reliable, fast, cheap and sensitive silver staining method to detect SSR markers in polyacrylamide gels. Biotechnol Agron Soc Environ 2006, 10:77-81.

39. Van Ooijen JW, Voorrips RE: JoinMap ${ }^{\circledR}$ version 3.0: software for the calculation of genetic linkage maps Wageningen: Plant Research International; 2001

doi:10.1186/1471-2164-12-266

Cite this article as: Whankaew et al:: A genome scan for quantitative trait loci affecting cyanogenic potential of cassava root in an outbred population. BMC Genomics 2011 12:266.

Submit your next manuscript to BioMed Central and take full advantage of:

- Convenient online submission

- Thorough peer review

- No space constraints or color figure charges

- Immediate publication on acceptance

- Inclusion in PubMed, CAS, Scopus and Google Scholar

- Research which is freely available for redistribution

Submit your manuscript at www.biomedcentral.com/submit 